\title{
GERAKAN DAN DAKWAH ISLAM \\ (PERAN MURJI'AH DALAM MEMBANGUN PERADABAN ISLAM)
}

\author{
Amir Hamsah $^{1}$, Asriadi $^{2}$ \\ ${ }^{1}$ Institut Agama Islam Muhammadiyah Sinjai \\ Email: puangamirhamzah@gmail.com,Tlp.:+6282188783286 \\ ${ }^{2}$ Institut Agama Islam Muhammadiyah Sinjai \\ Email: asriadiaccy92@gmail.com, Tlp : +6285343688717
}

\begin{abstract}
Abstrak
Murji'ah adalah golongan ketidak setujuan dengan pendapat kaum Khawarij, yang menghukumi kafir orang-orang yang melakukan dan menyetujui tahkim. Ajaran pokok murji'ah pada dasarnya bersumber dari gagasan atau doktrin irja yang diaplikasikan dalam banyak persoalan, baik politik maupun teologis. Aliran Murji'ah mengalami perkembangan, yaitu dengan terbagi menjadi sub-sekte yang kecil-kecil. Hal itu dikarenakan perbedaan pendapat yang bersifat internal tentang permasalahan-permasalahan yang muncul. Di bidang politik, doktrin irja diimplementasikan dengan sikap politik netral atau nonblok, yang hampir selalu diekspresikan dengan sikap diam. Golongan Murji'ah dibagi kedalam dua kelompok besar yaitu golongan moderat dan ekstrim sehinggga murjiah dianggap memiliki peran dalam permbangnan peradaban islam.
\end{abstract}

\section{Kata Kunci : Gerakan, Dakwah Islam, Murji’ah, Peradaban Islam, Doktrin}

\section{Pendahuluan}

Bani umayyah kekhalifahan islam pertama setelah masa khulafa urRasyidin yang memerintah dari (661-750 M) dijazirah arab dan sekitarnya. Merupakan masa peralihan dari Hasan bin Ali kepada Mu'awiyyah bin sufyan. Peristiwa tersebut termasuk masa perubahan sistem pemerintahan masyarakat islam. Banyak sistem pemerintahan pada masa khulafa ur-Rasyidin yang disempurnakan dan juga dirubah secara total. Serta melakukan perluasan diberbagai daerah, sehingga membuat peradaban islam berjaya.

Dinasti Umayyah didirikan oleh Muawiyah bin Abu Sufyan pada tahun 41H/661 M di Damaskus dan berlangsung hingga pada tahun 132 H/750 M. Nama Dinasti Umayyah dinisbatkan kepada Umayyah bin Abd Syams bin Abdu Manaf. Ia adalah salah seorang tokoh penting di tengah Quraisy pada masa 
jahiliyah. Ia dan pamannya Hasyim bin Abdu Manaf selalu bertarung dalam memperebutkan kekuasaan dan kedudukan (Ahmad Al-Usyairi: 2006, 181).

Berdinya dinasti Abbasiyah diawali dengan dua strategi, yaitu: satu dengan sistem mencari pendukung dan penyebaran ide secara rahasia, hal ini sudah berlangsung sejak akhir abad pertama hijriyah yang bermarkas di Syam dan tempatnya di Al Hamimah, sistem ini berakhir dengan bergabungnya Abu Muslim al-Khurasani pada jum'iyah yang sepakat atas terbentuknya dinasti Abbasiyah. Sedangkan strategi yang kedua dilanjutkan dengan terang-terangan dan himbauanhimbauan di forum -forum resmi untuk mendirikan dinasti Abbasiyah berlanjut dengan peperangan melawan dinasti umayyah. Dari dua strategi yang diterapkan oleh Muhammad bin Al-'Abasy dan kawan-kawannya sejak akhir abad pertama sampai $132 \mathrm{H}$ akhirnya membuahkan hasil dengan berdirinya dinasti Abbasiyah (Ahmad Al-Usyairi: 2006, 55).

Pada masa Daulah Abbsiyah disebut sebagai masa keemasan islam, atau sering disebut dengan istilah "The Golden Age". Pada itu masyarakat islam telah mencapai puncak kemulian, baik dalam bidang ekonomi, politik, peradaban dan kekuasaan pada masa kekuasaan bani Abbas yang pertama. Selain itu juga telah berkembang berbagai ilmu pengetahuan, ditambah lagi dengan banyaknya tokohtokoh penerjemahan buku dari bahasa asing ke bahasa Arab. Sehingga melahirkan cendekiawan-cendekiawan yang terkenal dalam bidang filsafat. Bani Abbas mewarisi imperium besar bani Umayyah. Hal ini menjadikan mereka lebih banyak, karena landasannya telah dipersiapkan oleh Daulah Bani Umayyah yang besar.

Ada eberapa aliran pada masa dinasti umayyah dan dinasti abbasiyah yang sangat menonjol, Pada era dinasti Umayyah ini adalah awal mula lahir dan berkembangnya sejumlah sekte teologi seperti Jabariyah, Qadariyah, Murji'ah dan Mu'tazilah (Ahmad Amin: 1952, 279). Meski demikian diakui bahwa puncak keemasan pertumbuhan intelektualisme dalam dunia Islam memang terjadipada era Abbasiyah.

Di lain pihak, Murji'ah merupakan aliran Theologi Islam yang netral atau menangguhkan dan memberi pengharapan terhadap ummat yang melakukan dosa 
besar, munculnya aliran ini pada mulanya ditimbulkan oleh persoalan politik.

kemudian akhirnya berkembang menjadi persoalan teologis. Kaum murjiah pada mulanya merupakan golongan yang tidak mau ikut campur dalam pertentangan-pertentangan yang terjadi ketika itu dan mengambil sikap menyerahkan penentuan hukum kafir atau tidak kafirnya orang-orang yang bertentangan itu kepada Tuhan. Dari lapangan politik mereka segera pula berpindah ke lapangan teologi. Persoalan dosa besar yang ditimbulkan kaum khawarij, mau tidak mau menjadi bahan perhatian dan pembahasan pula bagi mereka. Kalau kaum khawarij menjatuhkan hukum kafir bagi orang yang berbuat dosa besar, kaum murjiah menjatuhkan hukum mukmin bagi orang yang serupa itu. Adapun soal dosa besar yang mereka buat, itu di tunda penyelesaiannya ke hari perhitungan kelak.

\section{Pembahasan}

\subsection{Gerakan Dakwah dan Komunikasi Murji'ah}

Aliran Murji'ah merupakan salah satu aliran yang dipelajari dalam Teologi Islam. Munculnya aliran ini dilatarbelakangi oleh persoalan politik, yaitu soal khalifah (kekhalifahan). Setelah terbunuhnya khalifah Usman ibn Affan, umat Islam terpecah kedalam dua kelompok besar, yaitu kelompok Ali dan Mu'awiyah. Kelompok Ali lalu terpecah pula kedalam dua golongan yaitu golongan yang setia membela Ali (disebut Syiah) dan golongan yang keluar dari barisan Ali (disebut Khawarij). Ketika berhasil mengungguli dua kelompok lainnya, yaitu Syiah dan Khawarij dalam merebut kekuasaan, kelompok Mu'awiyah lalu membentuk dinasti Umaiyah. Syiah dan Khawarij bersama-sama menentang kekuasaannya. Syiah menentang Mu'awiyah karena menuduh Mu'awiyah merebut kekuasaan yang seharusnya milik Ali dan keturunannya. Sementara itu Khawarij tidak mendukung Mu'awiyah karena ia dinilai menyimpang dari ajaran Islam. Dalam pertikaian antara ketiga golongan tersebut, terjadi ditengah-tengah suasana pertikaian ini, muncul sekelompok orang yang menyatakan diri tidak ingin terlibat dalam pertentangan politik yang terjadi. Kelompok inilah yang kemudian berkembang menjadi golongan "Murji'ah" 
Sebagaimana halnya dengan kaum Khawarij, kaum Murji'ah pada mulanya juga ditimbulkan oleh persoalan politik, tegasnya persoalan khilafah yang membawa perpecahan di kalangan umat Islam setelah 'Usman Ibn 'Affan mati terbunuh. Seperti telah dilihat, kaum Khawarij, pada mulanya adalah penyokong 'Ali, tetapi kemudian berbalik menjadi musuhnya. Karena adanya perlawanan ini, penyokong-penyokong yang tetap setia padanya bertambah keras dan kuat membelanya dan akhirnya mereka merupakan satu golongan lain dalam Islam yang terkenal dengan nama Syi'ah. Kefanatikan golongan ini terhadap 'Ali bertambah keras, setelah ia sendiri mati terbunuh pula. Kaum Khawarij dan Syi'ah, sungguhpun merupakan dua golongan yang bermusuhan, sama-sama menentang kekuasaan Bani Umayyah, tetapi dengan motif yang berlainan. Kalau Khawarij meentang Dinasti ini, karena memandang mereka menyeleweng dari ajaran-ajaran Islam, Syi'ah menentang, karena memandang mereka merampas kekuasaan dari 'Ali dan keturunannya.

Dalam suasana pertentangan serupa inilah, timbul suatu golongan baru yang ingin bersikap netral tidak mau turut dalam praktek kafir-mengkafirkan yang terjadi antara golongan yang bertentangan itu. Bagi mereka sahabat-sahabat yang bertentangan itu merupakan orang-orang yang dapat dipercayai dan tidak mengeluarkan pendapat tentang siapa yang sebenarnya salah, dan memandang lebih baik menunda (arja'a) penyelesaian persoalan ini ke hari perhitungan di depan tuhan(Ahmad Amin: 1965, 279).

Al-Syahrastani mengemukakan bahwa orang pertama yang telah menemukan paham "irja” adalah Ghailan al-Dimasyqi, tetapi di tempat lain juga dikatakan bahwa pembawa ajaran ini adalah Hasan Ibn Muhahammad Ibn Ali Ibn Abi Thalib. Dan kemudian orang yang manganut paham ini di sebut dengan kaum "Murji'ah".

Mereka muncul sebagai reaksi terhadap pendapat kaum Khawarij yang mengafirkan orang-orang yang telah melakukan dosa besar, dalam hal ini adalah Ali Bin abi Thalib, Mu'awiyah, Amr bin Ash, Abu Musa al-Ash'ari. Dan lain-lain yang telah menerima arbitrase dan tahkim. Hal ini diawali oleh pertikaian dan oleh pertumpahan darah antara pengikut ali dengan pengikut Mu'awiyah Ibn Abi 
Sufyan yang memperebutkan masalah "khalifah” (Risan Rusli: 2015, 19)

Secara Umum, paham-paham Murji'ah dapat dilihat dari beberapa pendapat, sebagai berikut:

a. Rukun Iman ada dua yaitu Iman kepada Allah dan iman kepada Utusan Allah.

b. Orang yang berbat dosa besar tetap mukmin selama ia telah beriman, dan bia meninggal dunia dalam keadaan berdosa, maka segala keturunannya tergantung Allah di Akhirat kelah.

c. Perbuatan kemaksiatan tidak berdampak apa pun terhadap seseorang bila telah beriman. Selama meyakini dua kalimat syahadat, seorang mukmin yang berdosa besar tak dihukum kafir. Hukuman terhadap perbuatan manusia ditanggungkan, artinya hanya Allah yang berhak menjatuhkannya di Akhirat (Nunu Burhanuddin: 2016, 73)

Menurut Al-Baghdadi, kaum Murji'ah terbagi menjadi tiga golongan, yaitu al-Murji'ah Qadariyah, Murji'ah jabariyah, dan Murjiah yang keluar dari Qadariyah dan Jabariyah yang menjadi lima jenis, yaitu Al-Yunusiyah, AlGhassaniyah, Al-Tumaniyah, Al-Tsaubaniyah dan Al-Marisiyah.

Menurut harun nasution bahwa Murji'ah mempunyai dua golongan besar, golongan moderat dan golongan ekstrem. Adapun menurut al-Syahrastani dapat digolongkan menjadi empat, yaitu Murji'ah al-khawarij, Murji'ah al-Qadariyah, Murji'ah al-Jabariyah dan Murji'ah al-khalishah. Al-murji'ah al-Khalishah dapat dibagi menjadi tujuh bagian : al-Yunusiah, al-Ghassaniyah, al-Tumaniyah, alTsaubaniyah, al-Marisiyah, al-Ubaidiyah, al-Shalihiyah. Berarti pendapat alBaghdadi hampir sama dengan pendapat al-Ayahrastani (Risan Rusli: 2015, 23 24)

Secara umum, aliran Murji'ah terbagi mendai kelompok moderat (dipelopiri hasan bin Muhammad bin Ali bin Abi Thalib, abu Hanifah, Abu Yusuf dan baberapa ahli Hadits) dan kelompok ekstrem (dipelopori Jaham bin Shofwan).

Pertama, Golongan Murji'ah Ekstrem. Golongan ini dipimpin AlJahamiyah (pengikut Jaham ibn Safwan) paham berpendapat, bahwa orang islam yang percaya pada tuhan dan kemudian menyatakan kekufuran secara lisan tidaklah kafir, sebab iman dan kafir bertempat dihati. Yaang termasuk kelompok 
Murji'ah Ekstrem yaitu:

a. Aliran Al-Jamaiyyah, pengikut Jahm bin Shafwan

b. Aliran Al-Shalihiyyah, yakni pengikut Abu Al-Hasan Al-Salihi

c. Aliran Al-Yunusiyah, pengikut yunus bin Aun al-Namiri.

d. Aliran Al-Ubaidiyah, Pengikut Ubeid al 1-Muktaib.

e. Aliran Al-Ghassaniyyah, pengikut Ghassan al-kufi (Nunu Burhanuddin: 2016, 76)

Kedua, Golongan Murji'ah Moderat adalah Al-Murji'ah al-Sunnah yang pada umumnya terdiri dari para fuqaha dan muhaditsin. Yang termasuk golongan Al-Murji'ah Moderat diantaranya al-Hasan bin Muhammad Ali bin Abi Thalib, Abu Hanafi, Abu Yusuf dan beberapa ahli Hadits (Amin Nurdin: 2014, 15-28)

Ada beberapa teori yang berkembang mengenai asal-usul kemunculan Murji'ah. Teori pertama mengatakan bahwa gagasan irja atau arja'a dikembangkan oleh sebagian sahabat dengan tujuan menjamin persatuan dan kesatuan umat Islam ketika terjadi pertikaian politik dan untuk menghindari sektarianisme. Murji'ah sebagai kelompok politik maupun Teologis, diperkirakan lahir bersamaan dengan kemunculan Syi'ah dan Khawarij. Yang mana kelompok Murji'ah merupakan musuh berat Khawarij (Montgomery Watt: 1987, .23).

Teori lain mengatakan bahwa ketika terjadi perseteruan antara Ali dan Muawiyah, dilakukan Arbitrase (Tahkim) atas usulan Amr bin Ash (kaki tangan Muawiyah). Kelompok Ali terpecah menjadi dua kubu, yang pro dan kontra. Kelompok kontra yang akhirnya menyatakan keluar dari Ali disebut Khawarij. Khawarij berpendapat bahwa Tahkim bertentangan dengan Al-Qur'an atau dalam pengertian, tidak bertahkim berdasarkan hukum Allah dikatakan dosa besar dan pelakunya dihukumi dengan kafir sama dengan perbuatan dosa besar lainnya, seperti: berzina, riba, membunuh tanpa alasan, durhaka kepada orang tua, dan menfitnah wanita baik-baik. Pendapat tersebut ditentang sekelompok sahabat yang kemudian disebut Murji'ah. Murji'ah mengatakan bahwa pembuat dosa besar tetap mukmin, tidak kafir sementara dosanya diserahkan kepada Allah, apakah dia akan diampuni atau tidak (Montgomery Watt: 1987, .21). 
Adapun secara istilah, murjiah adalah kelompok yang mengesampingkan atau memisahkan amal dari keimanan, sehingga menurut mereka suatu kemaksiatan itu tidak mengurangi keimanan seseorang (Abdul Rozak: 2001, 56).

Tokoh utama aliran Murji'ah ialah Hasan bin Bilal Al-Muzni, Abu Salat As-Samman, dan Tsauban Dliror bin 'Umar. Penyair Murji'ah yang terkenal pada pemerintahan Bani Umayah ialah Tsabit bin Quthanah, mengarang syair kepercayaan-kepercayaan kaum Murji'ah (Nasir: 2010, 152)

Dari penjelasan diatas memberikan pemahaman tentang perseturuanperseteruan antara aliran, golongan ataupun sekte, yang lebih mengagatakan dan pendapat masing-masing kaum mengklaim, bahwa aliran yang diluar dari golongan mereka adalah orang-orang kafir dalam artian aliran yang benar adalah alirannya dari golongan yang mereka anut. Kemudian jika dikaitkan dengan kajian teori kominikasi pembahasan diatas penulis menyimpulkan bahwa pendekatan ataupun teori komunikasi yang dipakai adalah teori kendali organisasi.

Phili tompkins, George Cheney dan rekan-rekan mereka telah mengembangkan sebuah pendekatan yang baru dan berguna terhadap komunikasi organisasi. Para ahli teori ini tertarik dalm cara-cara komunkasi biasa membentuk kendali atas pegawai. Sebenarnya kendali dinyatakan dalam organisasi dengan emat cara. Pertama, kendali sederhana (simple conreol), atau penggunaan kekuasaan yang langsung dan terbuka. Kedua, kendali tekhnis (technical control), atau penggunaan alat-alat dan teknologi. Ketiga, Kendali birokrasi, yang merupakan enggunaan prosedur organisasi dan aturan-aturan formal. Keempat, konsertif (concertive control), pengguna hubungan interpersonal dan kerjasama tim sebagai sebuah cara kendali (Littlejohn: 2009, 378).

Dari teori kendali organisasi terebut diatas menyatakan bahwa, bagaimana tiap-tiap organisasi atau kelopok melakukan komunikasi organisasi agar mempertahandan dan menguatkan suatu kelompok yang di perjuangkan dengan melakukan beberapa hal dari keempat teori komunikasi kendali organisasi tersebut. kemudian di gabungkan dengan teori komunikasi politik atau komunikasi politik. Kalau kita berbicara tentang komunikasi politik maka perlu di 
perhatikan beberapa hal diantaranya ; 1). Sosialisasi Politik, 2). Partisipasi Politik, dan 3). Rekrutment Politik.

Sosialisai politik adalah keseluruhan proses untuk menyebarluaskan pesanpesan politik, termasuk informasi politik dan ideologi politik dari partai politik, melalui teknik komunikasi, propaganda atau kampanye. Partisipasi pilotik adalah sasaran dari sosialisasi politik, yaitu mendapatkan sumbangan pemikiran, tenaga dari sasaran politik, mereka tergabung di dalam bersama kita, memiliki informasi, ideologi dari organisasi politik. Rekrutmen politik adalah proses utuk menerima dan meningkatkan kualitas anggota baru di dalam sebuah organisasi politik (Alo Liliweri: 2010, 60)

Penggabungan dari teori kendali organisasi dan komunikasi politik memberikan sebuah jalan dan arah dari sebuah kelompok, organisasi, partai untuk lebih berkembang, berkualitas, kuat karena dengan adanya beberapa sumber penguatan dari teori-teori tersebut. bagaimana kelompok tersebut mempertahankan kelompoknya, ideologi, paham dan anggoranya dengan memperdayakan sumber daya yang ada pada kelompoknya tersebut.

\subsection{Doktrin Teologi Murji'ah}

Golongan Murji'ah ini mula-mula timbul di Damaskus, pada akhir abad pertama hijriah (Nasir: 2010, 162). Nama Murji'ah berasal dari kata irja atau arja'a yang berarti penundaan, penangguhan, dan pengharapan. Kata arja'a bermakna juga memberi harapan, yakni memberi harapan kepada pelaku dosa besar untuk memperoleh pengampunan dan Rahmat Allah. Selain itu, arja'a juga berarti meletakkan di belakang atau mengemudikan, yaitu orang yang mengutamakan iman dari pada amal. Oleh karena itu, Murji'ah artinya orang yang menunda penjelasan kedudukan seseorang yang bersengketa (yakni Ali dan Muawiyah serta pengikut masing-masing) kelak di hari kiamat (Cyril Glasse: 1989, 288).

Pada dasarnya, ajaran Murji'aah bersumber dari gagasan Irja' atau Arja'a yang kemudian diaplikasikan kedalam banyak hal dari persoalan politik hungga merambah ke persoalan Teologis. Berkaitan dengan doktrin-doktrin murjia'ah itu 
sendiri ada beberapa ahli yang mengemukakan pendapatnya. Diantaranya menurut W. Montgmery watt merinci doktrin teologi murji'ah adalah sebagai berikut

1. Penangguhan keputusan terhadap Ali dan Mu'awiyah hingga Allah yang memutuskannya kelak di akhirat.

2. Penangguhan Ali sebagai khalifah ke empat dari khulafaurraasyidin.

3. Memberikan harapa kepada orang-orang muslim yang berdosa besar untuk memperoleh ampunan dari Allah SWT.

Kemudian abu A'la Al Maturidi juga berpendapat mengenai dua pokok doktrin ajaran Murji'ah yaitu sebagai berikut:

1. Iman adalah percaya adanya Allah dan Rasulnya saja, sedangkan perbuatan bukan termasuk suatu keharusan bagi adanya iman.

2. Dasar dari keselamatan adalah iman semata.

Berkaitan dengan doktrin teologi Murji'ah Montgomery dalam Rosihan $(2000,59)$ yang merinci sebagai berikut :

1. Penangguhan keputusan terhadap Ali dan Muawiyah hingga memutuskannya di akhirat kelak.

2. Penangguhan Ali untuk menduduki rangking ke empat dalam peringkat alKhalifah ar-Rasyidin.

3. Pemberian harapan (giving of hope) terhadap orang muslim yang berdosa besar untuk memperoleh ampunan dan rahmat dari Allah.

4. Doktrin-doktrin Murji'ah menyerupai pengajaran (mazhab) para skeptic dan empiris dari kalangan helenis.

Dalam Perspektif Murji'ah orang Islam yang berbuat dosa besar tidaklah menjadi, kafir, melainkan tetap mukmin persoalan dosa besarnya diserahkan kepada Tuhan dalam keputusannya kelak di hari perhitungan. Kalaulah dosa besarnya itu diampuni Tuhan maka jelas ia akan masuk surga. Akan tetapi misalnya tidak diampuni Tuhan maka harapan bagi orang/pelaku dosa besar untuk diberi ampun oleh Tuhan sehingga seterusnya dapat masuk surga (Harun Nasution, 1986; 34)

Dasar argument dari pandangan teologis kaum Murji'ah ini ialah dengan satu asumsi bahwa orang islam yang melakukan dosa besar masih mengucapkan 
dua kalimah syahadah. Maka orang serupa ini masih yakin dan bukan kafir atau musyrik. Oleh karena itu inti ajaran yang paling luas dibicarakan dikalangan Murji'ah antara lain: iman, kufur, dan dosa besar, yang dalam tahap perkembangan lebih lanjut berkaitan pula dengan persoalan-persoalan teologis yang lain. Berdasarkan beberapa pendapat diatas, maka inti dari faham murji'ah iman adalah meyakini atau percya adanya Allah SWT dan Rasulnya, sedangkan orang yang melakukan dosa besar ia tetap mukmin. Letak iman berada didalam hati. Jadi amal perbuatan bukan merupakan iman. Tidak ada yang bisa menghapus keimanan, tetapi semua diserahkan pada Allah untuk menentukan hukumnya.

\subsection{Peran Murji’ah dalam membangun Peradaban Islam}

Aliran teologi al-Murji'ah pada awal pertumbuhannya mempersoalkan politik, yaitu tentang sikap tidak mau ikut campur dalam pertentangan setelah terbunuhnya Usman bian Affan dan menyerahkan penentuan kafir atau tidak kafirnya orang-orang yang bertentangan itu kepada Tuhan di akhirat nanti. Dari lapangan politik, segera berindah kelapangan teologi. Berbagai persoalan yang dibicarakan menurut, Ahmad Amin, adalah berkisar pada pembahasan tentang iman, kufur, mukmin dan kafir. Topik pembahasan tersebut dibicarakan kerena melihat golongan Khawarij melontarkan tuduhan kafir kepada yang lain, demikian pula golongan Syi'ah. Orang-orang yang berbuat dosa besar telah menjadi kafir, begitu pendapat golonganal-Khawarij. Kaum Syi'ah memasukkan ketaatan kemada iman sebagai salah satu rukun iman. Kemudian masuklah dalam pembahasan : apakah iman itu, dan apakah kufur itu? Kaum al-Murjiah berpendapat bahwa iman adalah mengetahui allah dan rasul-rasulnya (Amin Nurdin: 2014, 25-26).

Aliran Murjiee ah muncul dengan mengusung keyakinan lain mengenai dosa besar. Masalah yang mulanya hanya bersifat politis akhirnya berkembang menjadi masalah teologis. Lantara dua aliran tersebut muncul mendahului aliran Muetazillah, maka tidak salah pula jika Wolfson menyebut bahwa keduanya sebagai aliran pra-Muetazilah dalam teologi islam (Hamka Haq : 2007, 32).

Munculnya golongan murji;ah pada dasrnya merupakan antitesa terhadap keberadaan dari kaum syiah dan khawarij yang secara garis besar membicarakan 
tentang khalifah (polotik), kekufuran dan masalah keimanan karena merupakan antitesa, maka ajaran-ajaran pokoknya juga berkisar pada hal-hal yang sudah berkembang, seperti tentang keimanan, pengkafiran, dosa besar dan pemerintahan (Amin, 1961).

Kehadiran kelompok Murji'ah sangat mengejutkan umat islam, karena tidak mau mengkafirkan salah satu golongan suatu missal kaum khawarij yang menganggap kelompok syi'ah telah berbuat kafir kearea tidak menegakkan hukuman berdasarkan al-Qur'am. Sedangkan kaum syi'ah menuduh kaum Khawarij juga telah kafir karena firqah (terpecah dari jama'ah) yaitu keluar dari barisan syi'ah. Sedangkan pendukung Muawiyah juga megatakan kedua kelompok tersebut telah berbuat firqah dari jama'ah. Menanggapi perbedaan politik tersebut Muawiyah berbendapat bahwa demi menjaga persatuan ummat islam yang sangat besar jumlahnya maupun wilayahnya diperlukan kedamaian, kesejukan dan toleransi. Maka mereka menerima pemerintahan Muawiyah sebab secara rill sudah berjalan, sedangkan masalah akidah menyerahkan status hukumnya kepada Allah SWT sehingga tidak terjadi pertikaian antar umat Islam (Muhammad Nurdin: 2017,142)

Ajaran pokok Murji'ah ektrim diukur dari “ kelebihan” pandangan yang dikemukakan secara radikal dibanding orang Murji'ah yang tergolong moderat. Pengertian iman menurut kelompok ini hanyalah ma'rifah saja kepada Allah. Ma'rif yang dimaksud hanyalah cukup mengetahui terhadap Allah tidak perlu dengan ucapan lisan apalagi dengan pembuktian melalui perbuatan. Pengakuan dengan dengan ucapan lisan dan pembuktian dengan perbuatan bukan bagian dari iman. Karena itu bagi orang yang telah 'ma'rifah" tersebut sekalipun mengatakan kekufuran secara lisan tidaklah akan menjadi kafir ia tetap iman bahkan ia tidak menjadi kafir kendati menyembah berhala, menyembah salib. Percaya pada doktrin trinitas dan sebagainya, imannya tetap sempurna, ini terjadi karena iman dan kufur tempatnya di dalam hati bukan dalam prilaku anggota tubuh manusia (Al-Asya'ari : 198). 


\section{Penutup}

Semenjak wafatnya Rasulluah para sahabat banyak mengalami kesulitan dan perseturuan antara para sahabat, dan membuat membuat Aliran, golongan dan sekte-sekte ketika tidak sepaham atau sependapat pada ideologi masing-masing. Dengan munculnya bebarapa aliran menyebabkan semakin banyak perselisihan ideologi antara kaum, sehingga hanya membenarkan golongan atau aliran yang mereka ikuti masing-masing (ideologi yang dianut).

Sebagai sebuah aliran teologi, Murji'ah sudah menghilang dari pentas sejarah, dalam aspek teologi, lontaran gagasan pemikiran teologis Murji'ah sedikitnya memiliki tiga kecendrungn. Pertama, mengilhami lahirnya pemikiran teologis yang bersifat atau bercorak pasif. Kecendrungan kedua, dari kalangan Murji'ah meskipun dianggap mereka menghalang memberikan kecendrungan pada mnculnya gagasan yang sifatnya liberal dalam berteologi, atau bahkan karena ektrimitasnya dapat merimplikasi negatif sampai ke tahap nihilism moral, yang tidak kalah menariknya justru pada kecendrungan ketiga, yaitu menimbulkan semacam doktrin teologi pengharafan maaf.

Dalam aspek politik, sekalipun reputasi dalam memainkan peran politik tak spektakuler: dan kecendrungan pasif mungkin karena pengaruh faham " alIrja" tetapi nampaknya juga melahirkan tipologi perilaku politik unik. Kecendrungan prilaku politik yang unik memunculkan juga pendapat yang beragam, dari tipe yang pasif, ada pula nampaknya prilaku adaptif diikuti dengan sikap fleksibilitas dan loyalitas yang tentu tidak semuanya terkemuka dalam sejarah. 


\section{DAFTAR PUSTAKA}

A. Amin, Fajrul Islam, (ed.1) Leiden: Srill, 1961.

Abdul Rozak, Rosihon Anwar, Ilmu Kalam, Bandung: Pustaka Setia, 2001.

Ahmad Al-Usyairi, Sejarah Islam Sejak Zaman Nabi Adam Hingga Abad XX, Jakarta: Akbar, 2006.

Ahmad Amin, Fajr al-Islam, Kairo: Maktabah al-Nahdah, 1965.

Alo Liliweri, Strategi Komunikasi Masyarakat, Yogyakarta; LkiS, 2010.

Cyril Glasse, The Concise Encyclopedia Of Islam. Staccny International, London: 1989.

Hamka Haq, Al-Syatibi, Jakarta: Erlangga, 2007.

Harun Nasution, Teologi Islam Aliran - aliran Sejarah Analisa Perbandingan, UI Press, Jakarta, 1986

M. Amin Nurdin, Afifi Fauzi Abbas, Sejarah Pemikiran Islam, Jakarta: Amzah, 2014.

Muhammad Nurdin, Peran Aliran Murji'ah dalam membangun kehidupan toleransi di masa modern, Kudus: Fikrah Jurnal Ilmu Aqidah dan Studi Keagamaan, Vol 5 No.1. 2017

Nasir, Sahilun A, Pemikiran Kalam(Teologi Islam), Jakarta: Rajawali pers, 2010.

Nunu Burhanuddin, “Ilmu Kalam Dari Tauhid Menuju Keadilan”, Jakarta: Kencana, 2016.

Risan Rusli, Teologi Islam: Telaah Sejarah dan Pemikiran Tokoh-tokohnya, Jakarta: Kencana, 2015.

Stephen W. Littlejohn, Teori Komunikasi, Jakarta: Salemba Humanika, 2009.

W.Montgomery Watt, Islamic Philosophy and Theology:An Extended Survey.At Univ, Eidenburgh: Press, 1987. 